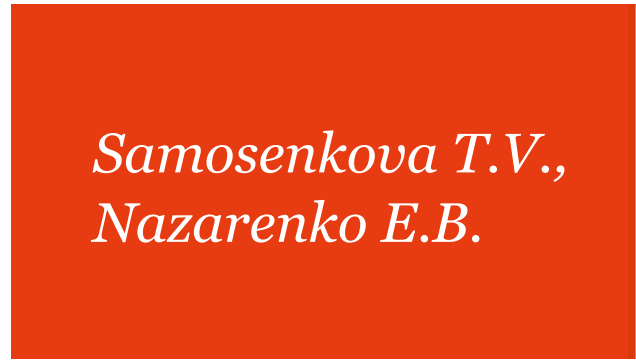

\title{
PSYCHOLOGICAL AND \\ PEDAGOGICAL PECULIARITIES \\ OF TEACHING FOREIGN \\ UNDERGRADUATE STUDENTS \\ AT THE RUSSIAN UNIVERSITY
}

\section{Samosenkova Tatyana Vladimirovna,}

Doctor of Education, Professor

Belgorod State National Research University,

85 Pobedy St., Belgorod, 308015, Russia;

E-mail: samosenkova@bsu.edu.ru

Nazarenko Elena Borisovna,

$P h D$ in Education, Associate Professor

Belgorod State National Research University

85 Pobedy St., Belgorod, 308015, Russia

E-mail: Nazarenko_e@ bsu.edu.ru

Самосенкова Татьяна Владимировна,

доктор педагогических наук, профессор

Белгородский государственный национальный исследовательский

университет, ул. Победы, 85, г. Белгород, 308015, Россия;

E-mail: samosenkova@bsu.edu.ru

Назаренко Елена Борисовна,

кандидат педагогических наук, доцент

Белгородский государственный национальный исследовательский университет, ул. Победы, 85, г. Белгород, 308015, Россия;

E-mail: Nazarenko_e@ bsu.edu.ru

\section{Abstract}

$\mathrm{T}$ The article is devoted to the problem of improvement of professional training of bachelors in Russian language on the basis of psychological and pedagogical features, which is topical nowadays. While training foreign bachelors it should be taken into account that the language and speech ability is one of the mental functions of a person. It can develop like all others mental functions which is due to innate instincts and human interaction with the environment and the process of studying, and its development may last throughout life under favorable conditions which include, in our opinion, the diversity and richness of incentives supported by emotions and personally meaningful experiences and the cultivation of all kinds of sensations and perception in foreign students. Such full immersion into the Russian language contributes to the growth of attention, memory, thinking and imagination that enables training material to remain permanently in the minds of the students.

K cognitive abilities; motivation. 
When considering the problem of foreign students training in the professional communication it is necessary to emphasize that the personal characteristics peculiar to a future specialist that play a definite role in their training and further professional activity have special importance, because the effectiveness of the learning process depends on the age, psychological and individual peculiarities of a foreign student-bachelor.

The problem of the age classification of undergraduate students in science is solved in different ways. In particular, N.N. Romanova considers bachelors of 1-2 courses as a "non-adult" age group, whose training is possible on the basis of pedagogical educational paradigm gradually replaced by an andragogical one. And only up to the third course the process of adaptation of recent school students to the University educational environment finishes and then their becoming an adult subject of the studying process occurs, where only an andragogical paradigm can be applied. [8, p. 90-104].

However, the period of school education of foreign students often ends at the age of 18-25 years (in comparison with Russian students). For this reason, we can consider a foreign student as a mature person. This in its turn defines the features of teaching foreign undergraduate students, which are as follows:

1) the awareness of being an independent, competent person; 2) the existence of a certain experience of educational activity; 3) the use of training activity as a means of mastering professional competence; 4) the immediate practical application of acquired knowledge, abilities, skills. In addition, the student's age, according to Gaponova S. A., «is definitive for many psychological characteristics. It is the time of the highest level of physical development, intellectual maturity, practically firm worldview, the development of will and emotional sphere, sustainable motivation when temperamental nature can be considered as established as well» [1, p.103].

As for the cognitive characteristics of such students, they are almost formed: they have a certain level of erudition and possess a wide range of logical operations (analysis, synthesis, comparison, classification, analogy, juxtaposition, classification, modeling, abstraction, etc.). Also they are characterized by the conscious- ness of action whereby the transition to abstract thinking is carried out almost without difficulty. Mentality is "a socially constructed, inextricably linked with a speech mental process of searching and discovering something new, a process mediated and generalized reflection of reality in the course of its analysis and synthesis" [6, p. 431]. Thinking as a cognitive mental process plays an important role in the process of language mastering, because it is the means and instrument of communication. A.V. Yarmolenko believes that "the training of foreign students occurs with the so-called "comprehension" of the system of a native language, thus comparison of a foreign language with a native one is inevitable (the author builds a model of associative relationships that arises in the mind of an adult learners of a foreign language which is as following: a foreign word $\rightarrow$ phenomenon $\rightarrow$ a native word [9, p. 34] .

The verbal-logical thinking is very important for bachelors and the level of its development directly influences the success of mastering a foreign language. V.V. Ryzhov highlights a specific component of an intellectual activity in the structure of foreign language abilities. The ability to linguistic generalization is defined by him as: "the quickness and correctness in determining the linguistic regularity, based on a limited number of linguistic rules and a simplicity of its shifting to other implementations, including the correct use of certain language rules while making new statements" $[7$, p. 48]. Therefore, in the learning process it is necessary to consider the competence of foreign students in the linguistic generalization (for example, find, and compare, change words etc. exercises are often used in making tasks aimed at independent mastering of lexical and grammatical material).

Peculiarities of memory play an important role in the psychological characteristics of undergraduate students. Let's discuss some known formed features of memory and memorizing of an adult in psychology: the ability of brain to forecast which is based on a past experience (Anokhin, 1970); the classification, systematization, notional memorization tendency of memory (Benedictov, 1974; Lyaudis, 1977; Minyar-Beloruchev, 1986; Sechenov, 1952; Smirnov, 1966); the possibility of increasing the information capacity of the memory by filling it with symbols, the more affluent in the information sense, by 
means of the more efficient organization of the material (Lyaudis, 1977).

The first of the features mentioned above has a significant value while learning a foreign language since it proves and explains the physiological necessity of appeal of the learner of the foreign language to the facts and phenomena of the native language. Imagination is "a transformation process of representations that reflects the reality and creation of new representations on this basis" [5, p. 284]. Due to the fact that the imaging process of a foreign student necessarily involves memory and thinking, emotional and volitional qualities, we can say that a highly developed imagination supports the more successful learning.

Another feature of the learning process is perception, that is "a complete reflection of objects, situations, and phenomena arising from the direct impact of physical stimuli on the receptor surface of the senses"[5, p. 200]. The process of perception affects the feeling, prior experience and the process of understanding of what is perceived. It is therefore evident: "the process of perception includes mental processes on even higher level, such as memory and thinking"[5, p. 201]. Of course, the perception of an adult is significantly higher developed than the perception of the child; therefore, we can state that an undergraduate student is more "prepared" for learning a foreign (Russian) language. In addition, the students have the developed directed attention of a sufficiently large volume, stability and intention to achieve a set objective.

Summarizing the above, we can conclude that the thinking of a student-bachelor is characterized by autonomy (by the ability to see and to put the new task and to solve it independently, by the flexibility, by the ability to modify the initial trajectory of the solution of the assigned task) and high speed of thinking; the memory has a unique approach to classification and systematization; the memory is characterized by a focus on classification and systematization; perception and imagination have a high level of development; attention is quite stable.

Another criterion of education of foreign students-bachelors is the specificity of motivation, which is a necessary component of successful learning activity. It plays a key role in the learn- ing process. In psychological dictionary [2, $\mathrm{p}$. 393] motive is interpreted as "the impulse to activity associated with the fulfillment of needs of the entity. The totality of such impulses causing the entity's activity represent a motivation". The motive is an obligatory component of any activity. Needs, interests, feelings, knowledge can act as motive. According to Kulikova's O.V. study $[4$, p. 84-85], the motivational sphere of foreign students has its own distinctive features, which are characterized as follows: 1) differentiation of indicators of social distance towards representatives of different countries within a study group; 2) the basis of self-esteem and emotional well-being of a foreign student in a foreign socio-cultural environment: the attitude of friends (the diaspora); 3) high ambitions in increasing intelligence, and low ambitions in gaining the authority of the teacher; 4) a shift in the strategy of interpersonal interaction while getting into another social and cultural environment: students become more benevolent toward representatives of the host country and less dominant, while in relation to compatriots they are more dominant; 5 ) the predominance of intrapersonal motives in motivation of educational activity, herewith the degree of effort is less inadequate than the level of claims and the desired results.

The motives of educational activity are the driving force that directs the student to active mastering of knowledge, abilities, skills (L.S. Vigotsky, A.N. Leontiev, S.L. Rubinshtein). Typically, five leading motives determining the focus of cognitive activity are distinguished: 1) professional; 2) of personal prestige3) pragmatic; 4) cognitive; 5) social. These motives characterize the personality characteristics of the adult student in different ways, what distinguishes him/ her, for example, from the pupil who is studying subjects in relation to the requirements of the school curriculum, with the need for stimulation etc. Long-term research, whose task was to study the motives of learning a foreign language by real students of Nizhny Novgorod State Linguistic University, was carried out by V. V. Ryzhov. According to the results of the study, 9 groups of motives were identified [7, p. 75-76]: 1) professionally-pedagogical; 2) informatively-educational; 3) intellectually-developmental; 4) communicative; 5) emotionally-valuable 6) of 
prestige; 7) identification; 8) materially-practical (pragmatic); 9) of duty. The distribution of motives is as follows: the first place is taken by informative and educational motivation (overall rating of 39.8), on the second place is emotional motivation $(39,5)$, the third place belongs to the intellectually-developmental motivation $(37,2)$, the fourth place is occupied by professionally-pedagogical motivation $(36,1)$, communicative motivation is on the fifth place $(34,1)$, followed by the motives of duty $(33,3)$, motives of identification $(28,5)$, pragmatic motivation $(26,7)$, motivation of the ambition (prestige) $(22,9)$ [7, p. 77].

As can be seen, the first five places are occupied by the motives revealing a certain psychological maturity of students (unlike pupils), their autonomy, initiative and motivation, ability to correlate its training activities with professional priorities. This confirms that the study of the Russian language by foreign students is done consciously, with the availability of some life experience both educational and linguistic, thus, more or less efficiently regulating the learning process. Hence the teacher working with a foreign audience must consider the motivation of learning, which has the following features: foreign students of 1-3 years have a fairly stable motivation of learning, with the exception of the motivation of achievement, which drops in the 2nd year and then again recovers to its previous high level in consequence of some loss of confidence in the 2nd year. In the 4 th year, the manifestation of external, internal, academic and social motives decreases in students. Foreign students are not active in the learning process due to low confidence in the early achievement of results. This relates to the fact that foreign students live in the strange, alien social and cultural environment and experience an additional adaptation stress. With regard to gender differences of foreign students, the learning motivation is associated with the following differences: for girls motivation is directly linked to general self-esteem, the level of pretensions and self-esteem, orientation to respect of the teacher and is inversely connected with relationships outside the group; for boys the learning motives are directly related to the level of aspiration, self-esteem and is inversely associated with self-confidence [4, p. 126-128].
Another important aspect of motivation is the reason why a foreign student enters a Russian University. In accordance with the motive of choice of the University there were detected some differences in the level of learning motivation. Students who have opted the Russian universities because of low tuition fees have a higher motivation for getting knowledge than students who choose a Russian University following the advice of relatives. Motivation of foreign students is a multidimensional and multilevel system in which one of its components is highlighted. It is a professional orientation, the most generalized form of students' attitude to the profession, which is defined as "an interest in the profession and the urge to practice it" (L.I. Bojovich, M.S. Neymark, S.L. Rubinshtein and the others). Professional orientation is one of the main motives of the educational activity of foreign students, which also has some peculiarities. It passes specific stages, interrelated and appropriate to acquiring certain psycho-pedagogical knowledge, abilities, skills. Following G.O. Kolarikova [3, p. 54-55], we allocate the following stages of professional self-determination of students: Stage 1. Adaptation (1st term of the 1st year): acquaintance of foreign students with the selected specialty, learning about the traditions of the faculty and the University, adaptation to the educational environment of the chosen University, the cultural environment of the city. Stage 2. Forming (2nd term, 1st year - 2nd year): the deepening and systematization of specialized knowledge, formation of professional-personal qualities, practical skills, self-knowledge and self-assertion in relation to the chosen profession. Stage 3. Practice-oriented (the 3rd year): mastering the methods and techniques of application of acquired knowledge, abilities, skills, the creative approach to solving professional objectives. The active formation and combining of all components of professional identity of foreign students occurs. Stage 4. Corrective (4th year): diagnostics of the level of formation of professional self-determination of foreign students and adjustment of its separate components. Derived knowledge and skills turns to reasonable forms of professional behavior. The main result of this phase is the preparation and protection of final qualifying work, which is regarded as the readiness 
of a foreign student to professional activity. The objectives and ways of their own professional activity are being defined. An important aspect in the process of professional self-determination of foreign students is their adaptation to new social conditions. Thus we have determined that the motivation of foreign undergraduate students has its own characteristics: individually-psychological, socio-psychological, and professionally directed. In the process of training of foreign undergraduate students a lecturer should take into account the peculiarities of psychic cognitive processes (thinking, memory, attention, perception, imagination), peculiarities of motivation and the existing educational and linguistic experience of the students. These features are the basis of study of bachelors.

\section{REFERENCES:}

1. Gaponova S. Developmental Psychology. N. Novgorod: Izd-vo NGPU. 1999. 112 p.

2. Great Psychological Dictionary / compilers and editors B.G. Meshcheryakov, V.P. Zinchenko // Moscow: AST: ST MOSCOW - St. Petersburg: Prime-EVROZNAK. 2009. $811 \mathrm{p}$.

3. Kolarkova O. Professional Self-determination of Foreign Students in Terms of a Pedagogical University. N. Novgorod. 2010. p. 261.

4. Kulikova O. Peculiarities of Learning Motivation of Foreign Students. Kursk. 2008. $192 \mathrm{p}$.

5. Maklakov A. General Psychology. St. Petersburg: Izd-vo Piter. 2000. 592 p.
6. Petrovsky A. Yaroshevskiy M.l. Psychology. Moscow: Izd-vo "Akademiya"; Visshaya shkola. 2001. 512 p.

7. Ryzhov V. Foreign Language Abilities. N. Novgorod: Izd-vo NGLU. 2001.

8. Romanova N. Linguo-didactic System of Professional-communicative Preparation of Specialists in the Higher Technical School. Moscow. 2009. 467 p.

9. Yarmolenko Au. The Ability to Multilingualism: Questions of Abilities. Moscow. 1962. $267 \mathrm{p}$. 